\title{
Overview of The Application of Risk Assessment on The Finishing Unit in PT. X 2017
}

\author{
Muhammad Aqila, Siti Rahmah Hidayatullah Lubis \\ Public Health Study Program, Faculty of Medicine and Health Sciences \\ Syarif Hidayatullah State Islamic University Jakarta, Indonesia \\ muhammad.aqila@gmail.com
}

\begin{abstract}
Risk assessment is one of the activities conducted by PT X to apply Occupational Safety and Health (OSH) in the company. Risk assessment in PT $X$ aims to identify potential hazard factors present in the workplace, assess hazard risk from hazard factors, determine control measures against existing hazards, prevent accidents and occupational diseases, and determine OSH program. This internship was conducted by the Occupational Health and Safety (OHS) unit and was conducted from February 1, 2017 until March 16, 2017. The finishing unit was selected because the unit has a greater hazards and risks than other units. Implementation of activities conducted by observation, interviews to workers and related officials, as well as review of accident data ever. The implementation of risk assessment in PT $X$ conducted from identifying the hazards and risks of observation, assessing the hazards and risks from the observation, interview and review data as well as determine its risk level by referring to the procedure used by the company. To complete this risk assessment, Job Safety Analysis (JSA) is also conducted for risks that are subject to High or Extreme and Risk Mapping risk to know where the risks in the unit are assessed risk. Suggestion given in the implementation of risk assessment in PT $X$ is by utilizing HIRADC document, OHS Executing Committee can create, understand and apply HIRADC, JSA and Risk Mapping documents on each unit, OHS unit can Pay more attention to risk assessment in the company and immediately update risk mapping when new location is held.
\end{abstract}

Keywords - Risk assessment; Finishing unit; Occupational Health Safety; Hazard

\section{INTRODUCTION}

The workplace must have a risk for an accident. It is undeniable that an accident will surely happen to someone if the person is not careful in reducing the danger. Based on data from the International Labor Organization (ILO) in 2013, one worker in the world two every 15 seconds due to workplace accidents and 160 workers affected by work-related illness [1].

By the end of 2015 there have been work accidents of 105,182 cases of work accidents in Indonesia. Meanwhile, for cases of serious accidents recorded as many as 2.375 cases of total number of accidents in Indonesia [2].

Occupational safety and health (K3) can be a solution to reduce the number of accidents that still high work. Hazards and OHS risks can be identified by identifying possible hazards and risks. Sometimes companies are committed to K3, but in practice, $\mathrm{K} 3$ is still a taboo for workers so there is no balance in the implementation of K3. Unbalanced K3 commitment with its implementation that causes the number of workplace accidents is still high.

PT $X$ is a company which are producing paper. Mananging risk is needed as make sure the risk in the workplace is safety or not. Risk management is the eradication or minimization of the adverse effects of risk to the organization exposed to such effects.

Based on the work accident data in PT X, finishing unit is a unit with the number of accidents is highest in five years back, which is 19 cases. Meanwhile, according to the interview with one of the HSE officer, finishing unit is a unit that has biggest population in PT X, so that accidents can occur due to the density of the population of workers.

\section{METHODS}

The information about application of risk assessment in PT $\mathrm{X}$ is obtained through observation, interviews to workers and related officials, and review of accident data ever. Observation are conducted around the company to see the implementation of the risk assessment. Interviews are conducted to workers and stakeholders who in charge in that unit. Reviewing accident data ever are conducted by looking at accident data to make sure the value of the risk assessment in that unit.

\section{RESULT}

PT $\mathrm{X}$ is a paper company that has main activities producing colour paper which consist of printing paper, copy paper, and many more. Finishing unit has selected because that unit has biggest hazard and risk than other units. Moreover, finishing unit has the most consistent accident in the last five years. PT $\mathrm{X}$ have procedures called "Hazard Identification, Risk Assessment, and Determining Control" to be aligned with procedure from company center. Procedures will be reviewed with the procedures from the company center.

The implementation of hazard identification and risk assessment in PT $\mathrm{X}$ done using observation and interview method which combined by using history data of accident at work. Identification hazard and risk in PT X using a form. Risk which has a value then evlaution through to the risk table level in procedures. 
Job safety analysis was doing according to the procedures, done against all activities in PT X which have hazard and risk potential. When implementation in PT X, JSA run for working activity which get risk level category high and extreme.

Implementation in PT X using form from company center which attached in Job Safety Analysis document:

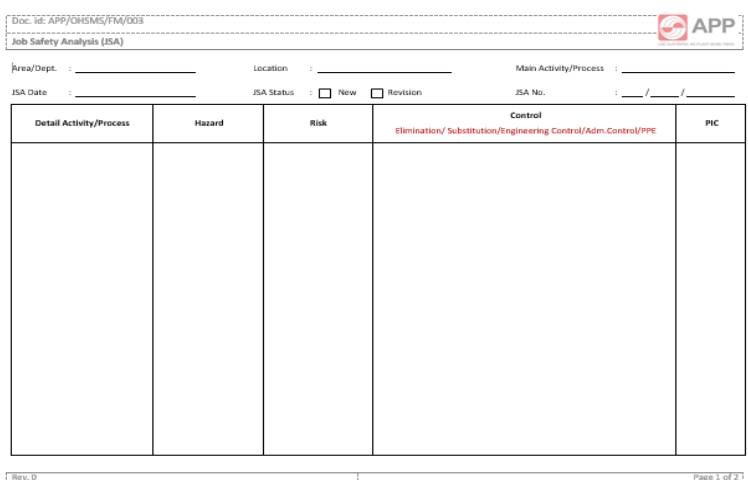

Fig 1. Form Job Safety Analysis page 1

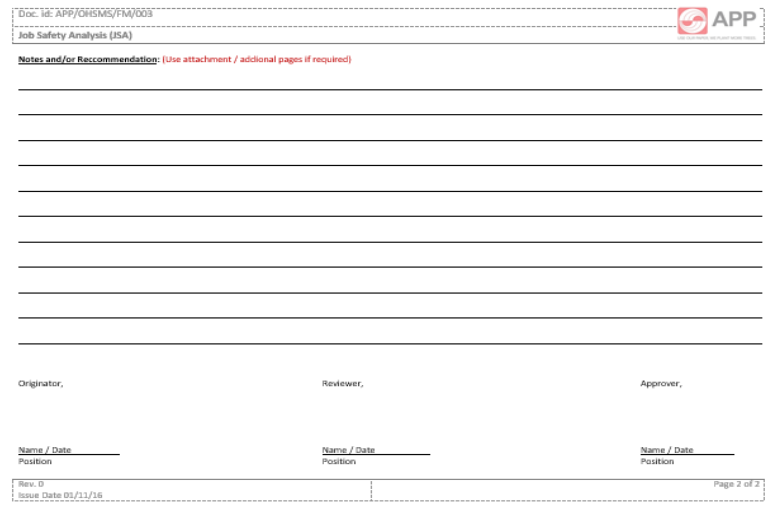

Fig 2. Form Job Safety Analysis page 2

Based on fig. 1 and 2, the important things to be written on the form job safety analysis is area/department, location, main process/activity, date, JSA status, and the number of JSA. Moreover, things will be written in JSA is detail activity from main activity, hazards, risks, control and PIC from that JSA. JSA can be added notes or recomendations which related with main activity. Then, who signed JSA is JSA organizer, reviewer, and stakeholder.

There is an example JSA result compiled by the author in finishing unit based on activities thaat have a risk level category high and extreme on rewinder 1 location:

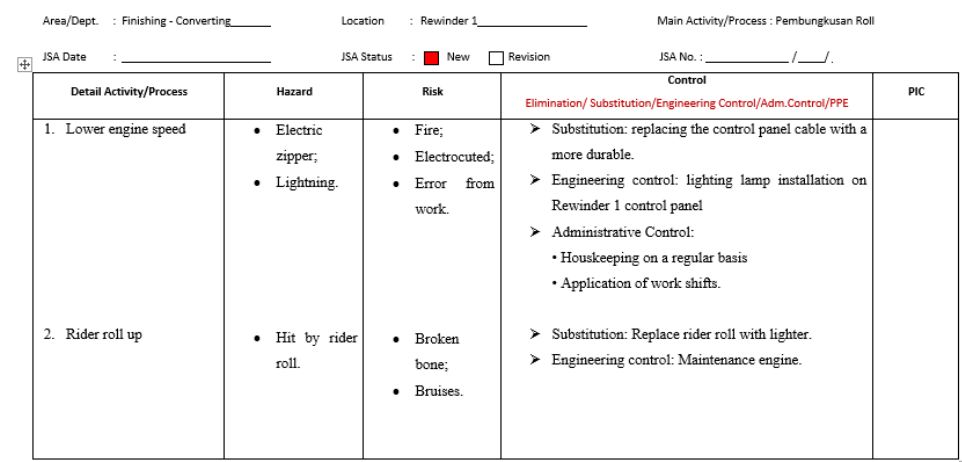

Fig 3. JSA Rewinder 1 page 1

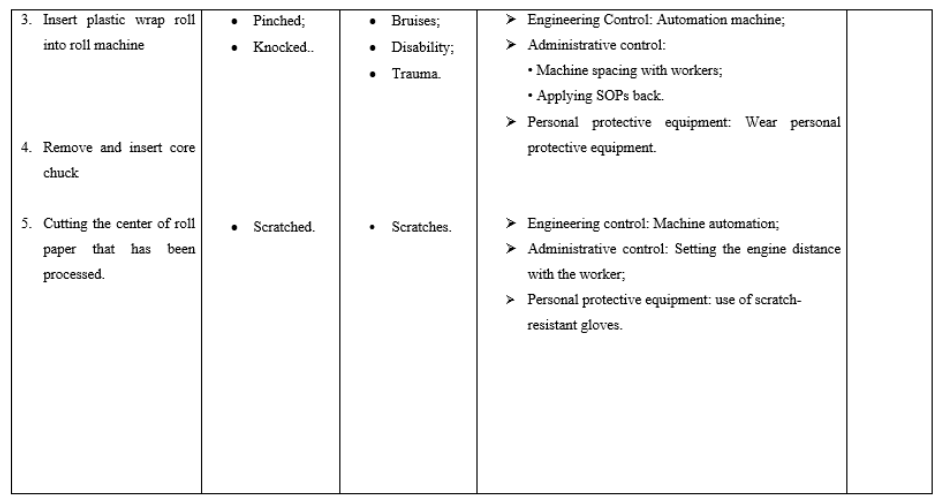

Fig 4. JSA Rewinder page 2

Based on fig. 3 and 4, the example taken is JSA which is in rewinder 1 with roll wrapping activity. The roll wrapping has five stages of detail activity such as lowering the engine speed, raising the roll rider, inserting the plastic wrapping roll into the engine roll, removing and inserting the core chuck and cutting the center of the processed roll paper. From the five stages, roll wrapping activities have several risks such as fire, electric shock, work errors, broken bones, bruises, severe defects, trauma, and scratches. To control such risks, the JSA must include some controls that have been designed based on the risks posed.

Risk mapping conducted in PT $\mathrm{X}$ is by dividing each category of risk assessment with the number of risks that exist in the category. After getting the total risk level per area, enter value to the risk level table in the procedure to see the color of the risk. Then color the risk mapping that has been made based on the map on the unit that conducted the risk mapping.

The following table 1 . is the result of the calculation of risk mapping already done by the author. 
TABLE 1. RISK RATE CALCULATION RESULTS OF EACH AREA IN THE FINISHING UNIT

\begin{tabular}{|c|c|c|c|c|}
\hline Area & $\Sigma$ Area & $\Sigma$ Equipment & $\Sigma$ Activity & $\Sigma$ Total \\
\hline Finishing office & 1 & 2 & 1 & 1 \\
\hline Sharpening blade & 2 & 2 & 1.5 & 2 \\
\hline Broke hallway & 2 & 2 & 3 & 2 \\
\hline Charger Accu & 2 & 2 & 3 & 2 \\
\hline Core Cutting & 2 & 2.5 & 2 & 2 \\
\hline $\begin{array}{l}\text { Bailling Press 1, 2, } \\
3 \\
\end{array}$ & 2 & 2 & 2 & 2 \\
\hline Pulper 3 & 2 & 0 & 3 & 2 \\
\hline Maintenance room & 2 & 2 & 2 & 2 \\
\hline Cyclops 1, 2, 3 & 2 & 1.5 & 2 & 2 \\
\hline Rewinder 1 & 2 & 2.5 & 2 & 2 \\
\hline Rewinder 2 & 2 & 2.2 & 2 & 2 \\
\hline Rewinder 3 & 2 & 2.5 & 2 & 2 \\
\hline Polar machine & 3 & 2 & 2 & 2 \\
\hline MC Mini Cutter 6 & 2 & 2 & 2 & 2 \\
\hline MC Mini Cutter 7 & 2 & 2 & 2.5 & 2 \\
\hline MC Mini Cutter 9 & 2 & 2 & 2 & 2 \\
\hline MC Mini Cutter 4 & 2 & 2 & 2 & 2 \\
\hline MC Mini Cutter 8 & 2 & 2 & 2 & 2 \\
\hline $\begin{array}{l}\text { MC Single Cutter } \\
1\end{array}$ & 2.5 & 2 & 3 & 3 \\
\hline $\begin{array}{c}\text { MC Double Cutter } \\
5 \\
\end{array}$ & 2 & 2.5 & 2 & 2 \\
\hline $\begin{array}{c}\text { MC Double Cutter } \\
10 \\
\end{array}$ & 2 & 2.5 & 2 & 2 \\
\hline $\begin{array}{c}\text { MC Double Cutter } \\
3 \\
\end{array}$ & 2 & 2 & 2 & 1.5 \\
\hline $\begin{array}{c}\text { MC Single Cutter } \\
2 \\
\end{array}$ & 2 & 2 & 2.5 & 2 \\
\hline $\begin{array}{l}\text { MC Mini Cutter } \\
15\end{array}$ & 2 & 2 & 2 & 2 \\
\hline $\begin{array}{c}\text { MC Mini Cutter } \\
16 \\
\end{array}$ & 2 & 2 & 2 & 2 \\
\hline MC Counting & 2.5 & 2.5 & 2 & 2 \\
\hline Unpack & 2 & 2.5 & 2 & 2 \\
\hline MC Wrapping & 2 & 2.5 & 2 & 2 \\
\hline MC MSK & 3 & 2.5 & 2 & 2.5 \\
\hline Rework & 2.5 & 2.5 & 1 & 2 \\
\hline $\begin{array}{l}\text { Unpack WIP } \\
\text { Warehouse }\end{array}$ & 2.5 & 2.5 & 2 & 2 \\
\hline Label storage & 2.5 & 2.5 & 2 & 2 \\
\hline $\begin{array}{c}\text { Packing material } \\
\text { user placement }\end{array}$ & 2 & 2.5 & 2 & 2 \\
\hline $\begin{array}{l}\text { Unsort (base paper } \\
\text { sort) }\end{array}$ & 2 & 2.5 & 2 & 2 \\
\hline Paper sorting & 2.5 & 2.5 & 1.5 & 2 \\
\hline Input sorting data & 2.5 & 2.5 & 2 & 2 \\
\hline Transit Unpack & 2 & 2,5 & 2 & 2 \\
\hline Cutting label & 2.5 & 2.5 & 2 & 2 \\
\hline $\begin{array}{c}\text { Wood Pallet \& } \\
\text { chipboard }\end{array}$ & 2.5 & 2.5 & 2 & 2 \\
\hline $\begin{array}{c}\text { Temporary Broke } \\
\text { pallet }\end{array}$ & 2.5 & 2.5 & 2 & 2 \\
\hline
\end{tabular}

Based on table 1 , all areas in the finishing unit have an average value of one to 2 which means all areas in the finishing unit have low risk level. So that all areas in the finishing unit obtain green color.

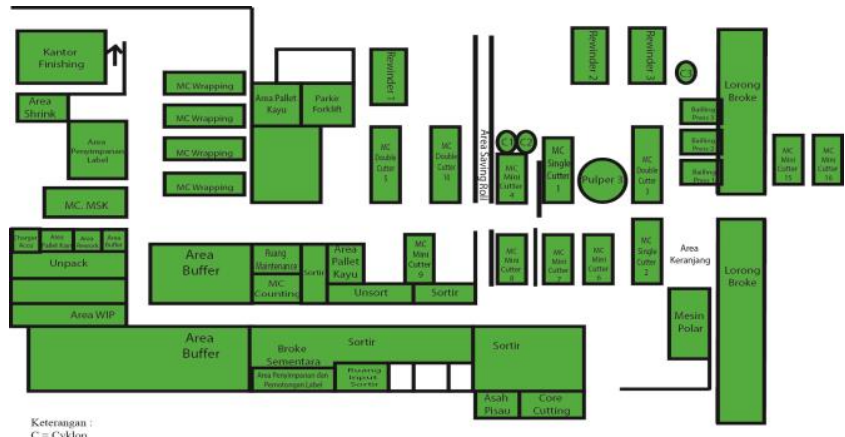

Fig 5. Risk maping finishing unit

Based on Fig. 5, all areas in the finishing unit that are reflected in the risk mapping created by the author are green. This means that all areas in the finishing unit have low risk with acceptable risk category. Whereas according to data HIRADC Finishing unit 2014, Finishing unit has medium risk level (medium) in some of its area. This indicates that the control that has been done on the Finishing unit has been successfully done. In addition, the decrease of accidents cases from year to year is also the reason why the risk maps are described in green.

\section{DISCUSSION}

Risk management is a key business process with between the private and public sectors around the world. Risk is a potentially harmful possibility (injury, pain, death) from exposure to hazard. Risk management can be defined as the eradication or minimization of the adverse effects of risk to the organization exposed to such effects. Risk assessment is one of the components of risk management. According to AS / NZS 4360: 20014 and ISO 31000: 2009, risk assessment is part of the risk management process. It can be seen from the chart of risk management process as follows:

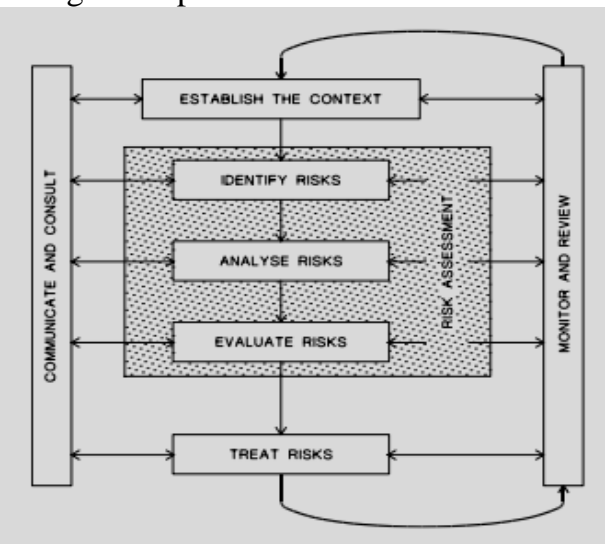

Fig. 6 Risk management process 
Based on that fig. 6, the stages of risk assessment are divided into three stages, namely risk identification, risk analysis, and risk evaluation. The three components are discussed at this stage of implementation of this activity [3].

Finishing unit has been choosen because that unit has risks and hazards biggest than other unit. According to the head of HSE unit in PT X, finishing unit is the unit that has the most consistent accident incidents in the last five years. In addition to the workplace accident rate, the finishing unit has a large area and a high nearmiss rate as well. Meanwhile, according to the holders of the risk management program, the finishing unit is the unit that has the largest number of workers than the other work units in PT X. This is what makes the finishing unit has the greatest risk than any other unit.

\section{A. Comparison of risk assessment policy between PT X and the company center}

There is a different between hazard identification, risk assessment, and determining control procedure owned by PT $\mathrm{X}$ and OHSMS Procedure Guidelines owned by company center, that is scope, definitions, references, general information, procedure and reponsibilities, special conditions, procedures, risk assessment, hazard review, job safety analysis, and form contained in the procedure risk assessment PT X and the company center.

In the OHSMS Procedure Guidelines, method used in risk assessment is through direct observation of on-the-job activities in the field. Implementation of risk assessment procedures is divided into three stages, that is hazard and risk identification, risk level assessment, and use of health and safety information to explain appropiate risk control and improvement plan.

\section{B. Implementation of hazard identification and risk assessment in PT X}

Hazard identification is a process that can be done to identify all situations or events that have potential to cause accidents and occupational diseases that may arise in the workplace [4]. Risk assessment is a comprehensive process in estimating the magnitude of risk and determine whether the risk can be tolerated. Based on the results of the risk identification process in each work unit related to the existing business process, then evaluated the risk sources and the causes of the risks that are further measured the likelihood of occurrence as well as the impact on the achievement of the company's performance. This risk assessment process will be used as a basis for creating risk mapping and establishing priority risk to be controlled [5].

Hazard identification and risk assessment are routine implementation by PT X every six months. According to PT X procedures (2015), hazard identification is the process of recognizing hazards and determining their characteristics. While the risk assessment is the process of evaluating the risks caused by the dangers with respect to the adequacy of controls owned and determine if the risks are acceptable or not. In addition, according to the company center procedures, risk assessment is the process of assessing the risks of identified hazards and then taking into account the adequacy of each current control, and deciding whether the risk is tolerable / acceptable.

Based on ISO 31000: 2009, in conducting hazard identification and risk assessment activities, the method used is the identification of risk sources, events, cases, and potential consequences. It can also use accident history data, theoretical analysis, information and opinions of experts and the need for power holders. In the implementation of hazard identification and risk assessment in PT X use the method of observation and interview to workers in the unit to be identified hazard and risk assessment. In addition to using such methods, the combined method to complement the identification result is the use of work accident history data [6].

Identified hazards and risks are then incorporated into a form, ie Hazard Identification, Risk Assessment and Controlling (HIRADC) formats. The following are examples of Hazard Identification, Risk Assessment and Controlling in PT X forms.

In the PT $\mathrm{X}$ forms, the first required component is the department or section and the location to be identified. After that the form is filled starting from the number, the type of risk assessment (area, equipment, activity), activities are routine / not routine, type of danger, human factor, risk, and initial assessment. In the initial assessment, filled in initial likelihood (LP) and severity (SV), then calculated into the value of the risk level to be included in the risk assessment matrix. Then described the initial risk level obtained at the work site. After that, attach the rules relating to the risks and set the control performed in managing those risks. Then specify the status of whether the control has been done or not. If the control has been done, do a final assessment where the method is the same as the initial valuation method. Attach supporting activities / HSE program if any to complete the hazard identification form, risk assessment and determination of such control.

There are three categories of risk assessment that must be done in PT X, which are area category, equipment category, and activity category. In the implementation of risk analysis, the method used is a quantitative method in which the likelihood value is multiplied by the severity value to obtain the risk level value. The value of the risk level can also be obtained through the risk assessment matrix. Risks that are already known are then evaluated. Risk evaluation is done by looking at the risk level table contained in the company center procedure. The risk analysis and risk evaluation reference here is company center procedure.

\section{Job safety analysis}

Job Safety Analysis in PT X run for work activity which get risk level category "High" and "Extreme" because that risk level category must be minimized as soon as possible until minimum reach risk level category "Medium". This research is in line with OSHA (2002) and CCOHS (2017) which said that the JSA is a technique to identify hazards on the stages of work before the work is performed. JSA focuses on the relationships between workers, jobs, equipment and the work environment. Because the hazards identified have to be minimized to acceptable risks. JSA can be used to review nonsurviving methods before a casualty. JSA is the first step in 
hazard and accident analysis in an effort to create work safety [7][8].

\section{Risk mapping}

Risk Mapping has been used by trade unions, environmental groups and other organizations in the United States, Mexico, Canada, Brazil and Italy to assess the risks of work and environmental pollution in the workplace, community and country level. According to US guidelines for mapping the risks made by the University of California's Labor Occupational Health Program (LOHP), said that the technique is done by drawing on the knowledge of workers and knowing their vital contribution. Risk Maps is developed every day, using experience on the job [9].

The following are the steps to make risk mapping [10]:

1. Identify the workplace to be conducted hazard mapping;

2. Risk assessment based on potential hazards present in the workplace;

3. Creating a grid and entering the assessment data into a risk mapping making program.

Risk Mapping conducted in PT X is by dividing each category of risk assessment with the number of risks that exist in that category. Then each category that has been divided by the amount of risks summed and subdivided by the number of categories. After obtaining the total risk level per area, enter the value to the risk level table in the OHS Management company center procedure. On the company center procedure, staining of each risk level is green to low, yellow for medium, orange for high, and red for extreme. Then after the color to be included in the risk mapping that has been made based on the risk level table contained in OHS Management company center procedures, color risk mapping that has been made based on the map on the unit conducted risk mapping. The following is the formula used in calculating the risk level in making risk mapping:

$\Sigma$ Total Risk Level $=(\Sigma$ Area Risk $+\Sigma$ Equipment Risk $+\Sigma$ Activity Risk) / 3

$\Sigma$ Area Risk $=$ A $/$ RA

$\Sigma$ Equipment Risk $=\mathrm{P} / \mathrm{RP}$

$\Sigma$ Activity Risk $=\mathrm{K} / \mathrm{RK}$

Information :

$\mathrm{A}=$ Total number of risk level of area category;

$\mathrm{P}=$ Total number of equipment risk rating levels;

$\mathrm{K}=$ Total number of risk levels of activity category;
$\mathrm{RA}=$ Total number of risks in the area;

$\mathrm{RP}=$ Total number of risks in equipment;

$\mathrm{RK}=$ Total number of risks in the activity

Suggestion that can be advised for PT $\mathrm{X}$ is to utilization of HIRADC documents should be taken into account in determining control in PT X. After that, OSH organizing committee in each unit can create, understand and apply HIRADC, JSA, and Risk mapping documents. Then, OSH Unit as the core implementer in PT $\mathrm{X}$ should be more concerned about the implementation of risk assessment in PT $\mathrm{X}$. And, immediately updete Risk Mapping when new location is held.

\section{REFERENCES}

[1] ILO, "Safety and health at work" [Online]. Available: http://www.ilo.org/global/topics/safety-and-health-at-work/lang-en/index.htm 2017], 2017

[2] Ministry of Health Indonesia, "One workers in the world death every 15 seconds because of work accident (1 Orang Pekerja di Dunia Meninggal Setiap 15 Detik Karena Kecelakaan Kerja)" [Online]. Jakarta: Kementerian Kesehatan Republik Indonesia. Available: http://www.depkes.go.id/article/print/201411030005/1-orang-pekerja-didunia-meninggal-setiap-15-detik-karena-kecelakaan-kerja.html 2017], 2014

[3] OHSAS, B. S, 18001: 2007. Occupational health and safety management systems. London, 2007

[4] TARWAKA, "Management and Implementation K3 in workplace (Manajemen dan Implementasi K3 di Tempat Kerja)", Surakarta, Harapan Press, 2008

[5] E. Andriani, "Hazard Identification and Risk Identification as Prevention of Accidents and Disease in Work on Ammonium Sulfat II Unit PT Petrokimia Gresik Jawa Timur (Identifikasi Bahay dan Penilaian Risiko Sebagai Upaya Pencegahan Kecelakaan dan Penyakit Akibat Kerja di Unit Ammonium Sulfat II PT Petrokimia Gresik Jawa Timur)”. Petrokimia Gresik Jawa Timur, 2010.

[6] ISO, I., 31000: 2009 Risk management-Principles and guidelines. International Organization for Standardization, Geneva, Switzerland, 2009.

[7] OSHA, Job Hazard Analysis, Occupational Safety and Health Administration, U.S Department of Labor, 2002.

[8] CCOHS, "Job Safety Analysis" [Online]. CCOHS. Available: http://www.ccohs.ca/oshanswers/hsprograms/job-haz.html 2017], 2017

[9] HAZARDS, Mapping Out Work Hazards. In: PUBLICATION, H. (ed.). Sheffield: Hazards Publications. 1997.

[10] H.K. Anwar, "Risk Maping of Occupational Health and Hazard on Chemical Laboratory PT PJB UBJ O\&M PLTU Paiton 9 Probolinggo District (Pemetaan Risiko Keselamatan dan Kesehatan Kerja Pada Area Laboratorium Kimia PT. PJB UBJ O\&M PLTU Paiton 9 Kabupaten Probolinggo)", undergraduate thesis, Jember University, unpublished. 